
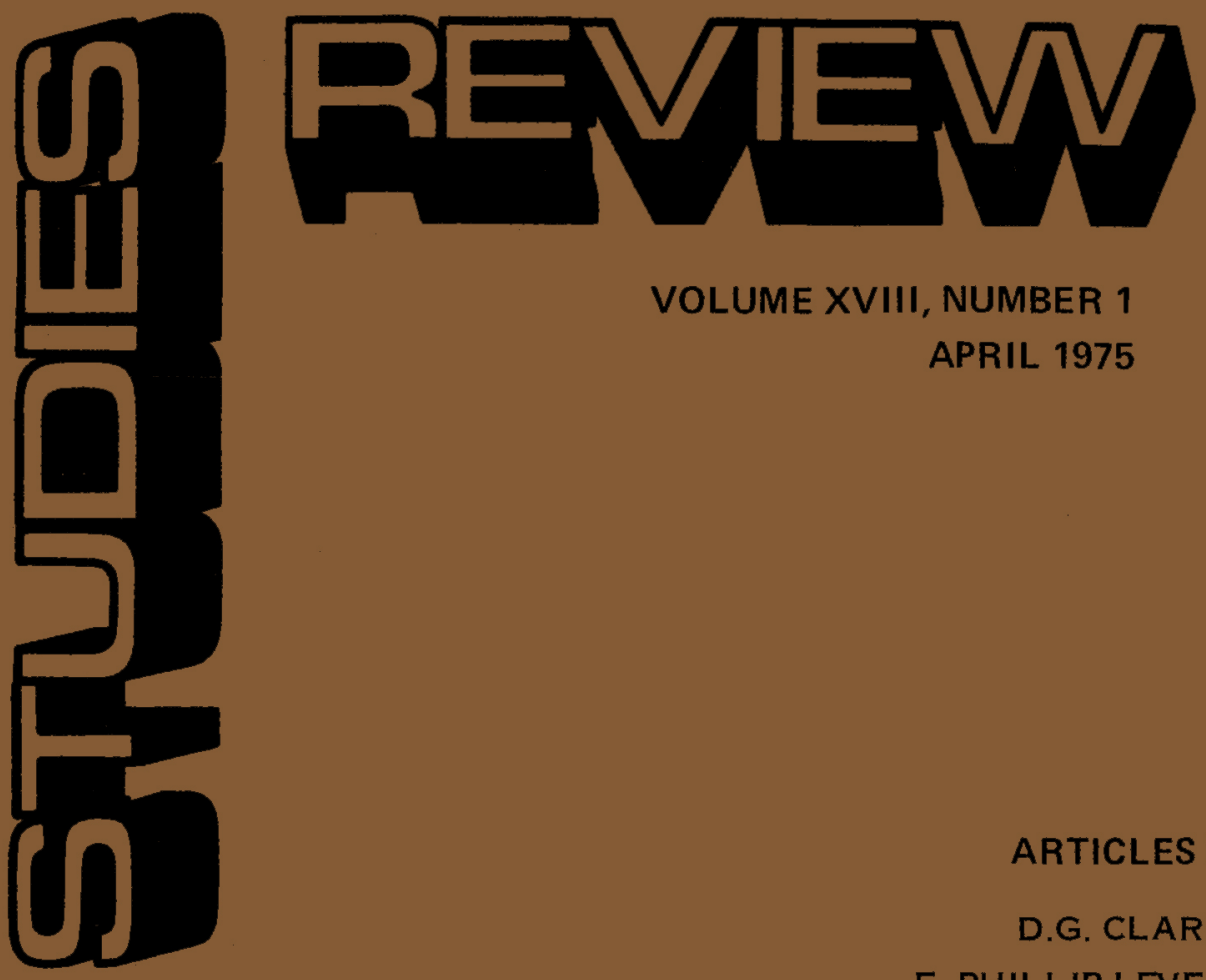

VOLUME XVIII, NUMBER 1

APRIL 1975

ARTICLES BY

D.G. CLARKE

E. PHILLIP LEVEEN

CAROL M. EASTMAN

THOMAS R. KNIPP STEPHEN P. HEYNEMAN

JAMES A. MCCAIN

FRANK A. SALAMONE KENNETH LEE ADELMAN LAURIE S. WISEBERG

Published by the AFRICAN STUDIES ASSOCIATION Edited by the PROGRAM OF EASTERN AFRICAN STUDIES Maxwell School, Syracuse University 
AFRICAN STUDIES REVIEW is edited and published three times a year (April, September, and December) by the Program of Eastern African Studies. The Maxwell Graduate School of Citizenship and Public Affairs, Syracuse University. The views expressed are the authors' and not necessarily those of the Association, its officers, or the Program of Eastern African Studies.

\author{
Editor \\ Alan K. Smith \\ Program of Eastern African Studies
}

\author{
Teaching Notes Editor \\ Evelyn Jones Rich \\ Director, School Services Division \\ African American Institute
}

\author{
Review Essay Editor \\ Hans E. Panofsky \\ Curator, Melville J. Herskovits Library \\ Northwestern University
}

Editorial Board: Rand Bishop (Literature, SUNY-Oswego); James L. Brain (Anthropology, SUNY. New Paltz); Ross Coates (Fine Arts, Russell Sage College); S.J. Cookey (History, Rutgers University); Neville Dyson-Hudson (Anthropology, SUNY-Binghampton); John D. Esseks (Political Economy, Northern Illinois); Judith L. Evans (Psychology, University of Massachusetts); Harvey K. Flad (Geography, Vassar College): Thomas H. Henriksen (History, SUNY-Plattsburgh); Milton R. Konvitz (Law, Cornell University); Germina Lubega (Economics, Hamilton College); Charles $\mathrm{H}$. Lyons (Education, Teachers College, Columbia University); C. Chinwoke Mbadinuju (International Relations, SUNY-Cortland); Alvin Magid (Political Science, SUNY-Albany); David W. McDowell (Education, SUNY-New Paltz); R. A. Obudho (Geography, Rutgers University); Victor C. Uchendu (Sociology, University of IIlinois, Urbana-Champaign); Norman Uphoff (Economics, Cornel1); Warren Weinstein (Political Science, SUNY-Oswego); Claude Welch (International Relations, SUNY-Buffalo).

Review Secretary: Mrs. Sarah L. LaMar

Assistant to the Editor: Peter T. Dalleo

The African Studies Review is a publication of the African Studies Association. Receipt of the Review, the African Studies Newsletter, and Issue (a quarterly journal of opinion on Africa) is automatic with membership in the Association. For information on membership, write the African Studies Association, 218 Shiffman Center, Brandeis University, Waltham, Massachusetts 02154.

Advertising information is available from the Association's office at Brandeis University.

Domestic claims for non-receipt of issues must be made to the Association's office within six months of the month of publication; overseas claims, one year. 
AFRICAN STUDIES REVIEW

Land Inequality and Income Distribution in Rhodesia

D.G. Clarke

The African Slave Supply Response

E. Phillip LeVeen

Ethnicity and the Social Scientist: Phonemes and Distinctive Features

Carol M. Eastman

Poets and Politics: Speculation on Political Roles and Attitudes in West African Poetry

Thomas R. Knipp

Changes in Efficiency and in Equity Accruing from Government Involvement in Ugandan Primary Education

Stephen P. Heyneman

Ideology in Africa: Some Perceptual Types

James A. McCain

The Serkawa of Yauri: Class, Status or Party?

Frank A. Salamone

The Church-State Conflict in Zaire: 1969-1974

Kenneth Lee Adelman

An Emerging Literature: Studies of the Nigerian Civil War

Laurie S. Wiseberg 


\section{ABOUT THE CONTRIBUTORS}

Duncan Clarke was formerly a lecturer in Economics at the University of Rhodesia. His principal research is involved with underdevelopment, income distribution, and labor in Southern Africa. His most recent work is Contract Workers and Underdevelopment in Rhodesia (Gwelo: Mambo Press, 1974).

E. Phillip LeVeen is an assistant professor of Agricultural and Resource Economics at the University of California, Berkeley. This work is an expansion of a section of his unpublished dissertation entitled "British Slave Trade Suppression Policies, 1821-1865: Impact and Implications"; a second related article, "A Quantitative Analysis of the Impact of British Suppression Policies on the Volume of the Nineteenth Century Atlantic Slave Trade," has recently been published in Race and Slavery in the Western Hemisphere, ed. Stanley Engerman and Eugene Genovese (Princeton University Press, 1974).

Carol M. Eastman is an associate professor of Anthropology and an adjunct associate professor of Linguistics at the University of Washington. Her regional specialty is Coastal Swahili language and culture and her most recent publication is Aspects of Language and Culture: Linguistics in an Anthropological Context (Chandler and Sharp, 1975).

Thomas R. Knipp is a professor of English and Dean of the College of Arts and Sciences at St. Louis University. A specialist in African Literature, he has taught in Ethiopia on several occasions, most recently as a Fulbright lecturer from 1968 to 1970 . His most recent publication is "Negritude and Negation: The Poetry of Tchikanga U'Tamsi" (Books Abroad, August 1974).

Stephen P. Heyneman is a senior scientist with the Social Research Group at George Washington University. He recently completed his doctoral dissertation, entitled "Influences on Academic Achievement in Uganda: A 'Coleman Report' from a NonIndustrialized Society," in Comparative Education at the University of Chicago.

James A. McCain is an assistant professor in the African and Afro-American Studies Department, State University College, Brockport, New York. In addition to ideology in Africa, his research interests include content analysis of the work of African leaders and methodologies used in African studies.

Frank A. Salamone, who formerly taught at State University College, Brockport, New York, is presently an assistant professor of Anthropology in the Department of Sociology and Anthropology, St. John's University. His research interests include social welfare work in Northern Nigeria and the forced migration following the building of Kainji Dam, Nigeria.

Kenneth L. Adelman, a doctoral candidate in Political Theory at Georgetown University, is a former government employee with the Office of Economic Opportunity and was a member of a Presidential Council studying poverty programs in the United States. In 1972, he moved to Kinshasa, Zaire, where he has been conducting research on Zairian religions, politics, and art. $\mathrm{He}$ is a frequent contributor to political science and art publications dealing with Africa.

Laurie S. Wiseberg is an assistant professor in the Department of Political Science, University of Illinois, Chicago Circle. Her publications include an article on "Humanitarian Intervention Lessons from the Nigerian Civil War," in the Journal of Human Rights, and a chapter entitled "International Perspectives on the African Famine" in a forthcoming book edited by Michael Glantz, to be published by Praeger Publishers. 